\title{
Some Ramifications of Good and Evil Medicine in Nazi Germany and Beyond
}

Can. J. Neurol. Sci. 2011; 38: 808-809

Lawrence Zeidman's account of physician resisters to the National Socialist regime generally and the Nazi medical regimen in particular is timely. ${ }^{1}$ Whereas medical crimes under Hitler have often been dealt with, the people resisting those crimes have just as often been neglected. This lacuna applies even in the case of German doctors who were caught up in the evil medical machinery. Hence Zeidman is right to treat the cases of Max Nonne and Karl Bonhoeffer, but in particular that of Alexander Mitscherlich. I should like to expand on him somewhat. Mitscherlich was interested in Freudian psychology, which was anathema to Nazi tenets. Hence Mitscherlich could come into his own as a Freudian analyst only after the end of World War II. More importantly, Mitscherlich was commissioned by the West German medical association to document medical-criminal cases then before the Allied courts. When a first book had been written, with the help of Mitscherlich's junior partner Fred Mielke, the association rejected it and eventually made sure that it did not reach the book market. The disenchanted medical student Mielke committed suicide in 1959, while Mitscherlich himself was prevented by German colleagues and authorities from occupying a chair in psychiatry, particularly in Heidelberg, the university he favored. It was after much delay that he became the prominent scholar as which the world now knows him.[1]

As far as those non-German medical resisters are concerned, the most impressive case for me is still that of the hundred Dutch doctors who refused to implement an unethical German medical protocol in occupied Holland and for that were sent to German concentration camps. This degree of heroism was unheard of among any of the German medical resisters Zeidman portrays. The Dutch physicians' compatriots were scores of foreign doctors, often Jewish, who had been caught in the raids and now were forced to aid the Nazis, either in questionable human experiments, as did the Hungarian doctor Miklos Nyiszli with Josef Mengele in Auschwitz, or helping fellow inmates in the camps.[2] Many died after being forced to commit crimes, as did several French doctors who had assisted Dr. Kurt Heissmeyer with tuberculosis experiments on small children in a hidden place in Hamburg. After the children had been hanged, the doctors were killed as well, to be rid of witnesses.[3] The pediatrician and children's book author Janusz Korczak joined his flock, a group of Jewish children, as they were being led to their deaths in gas chambers in Poland.[4]

The Germans' neglect of their physician heroes is the converse of the tolerance these same Germans have extended to medical-criminal villains for an uncommonly long time. Professor Otmar Baron von Verschuer, the Frankfurt teacher of Mengele who had benefited in many ways from the SS captain's fiendish "research," after 1945 never had to account for his role in this in a court of law and in 1951 returned to a chair at the University of Münster with full regalia, as a foremost medical geneticist.[5] On June 18, 2010, Dr. Hans Joachim Sewering died peacefully at his home in Dachau, at the age of ninety-four. In 1973 he had become the president of the West German Federal Physicians' Association (Bundesärztekammer), and in the early 1990s he almost was appointed head of the World Medical Association, but for the vigorous protests of Canadian, American and German researchers who had uncovered his shady past. As it turned out, Sewering had joined the SS in 1933, the Nazi party one year later, and then collaborated in the deaths of several, possibly hundreds, of "euthanasia" victims, killed in HaarEglfing, a facility near Dachau, and in psychiatric wards in Kaufbeuren. In his quest for the top international physicians' job, Sewering was staunchly supported by the Bundesärztekammer and its official organ, the Deutsches Ärzteblatt. The Ärzteblatt, which every German doctor reads, itself was slow to recognize the necessity of exposing the German medical establishment's sullied past, hewing to the old axiom (which Zeidman refers to), that no more than 350 German physicians had been implicated in Nazi crimes.[6]

Nazi medical crimes occurred within the confines of several concentric circles and often tainted men and women who initially had had nothing to do with medicine. They touched a certain Professor Hans Schwerte, who became the internationally respected rector of the Technical University of Aachen in the 1970s. Schwerte, who as a specialist in German literature had written a much-noted book on Goethe's Faust, in the 1990s was retired comfortably in South Germany when the news broke that in reality his name was Dr. Hans Schneider, a Germanist who as an SS captain had worked for Heinrich Himmler's ignominious research organization Ahnenerbe in the occupied Netherlands.[7]

As Dutch journalists had found out, after the war in 1945 Schneider had gone into hiding, only to resurface as Hans Schwerte, who ostensibly was eager to study German literature and obtain his doctorate in that field. This he did, working on Goethe, and telling no one of his real name and Nazi past, or that this would be his second doctorate in this specialized field. Of high intelligence, he succeeded, eventually obtaining the professorship at Aachen. While his wife - whom he had remarried to make the fraud complete - knew all the details of the evil charade, his small daughter at that time did not suspect anything, thinking her natural father had fallen at the front.

Schneider/Schwerte moved onto criminal terrain when as an SS cultural-control officer in occupied Holland he was asked to help in the search for pressure-chamber equipment. This was something Ahnenerbe researcher Dr. Sigmund Rascher needed, who at the concentration camp of Dachau was subjecting inmates to experiments in simulated great heights, at the end of which vivisection was carried out. As I know from primary documents, Schneider/Schwerte conducted searches at Dutch universities and possibly aided Rascher in person, who also exposed inmates to ice water until they died. By way of 
conclusion, I find it shocking that a specialist in German literature should become involved, or agree to become involved, in "experiments in great heights," perpetrated on innocent men who would subsequently be murdered. This is how bad medicine could compromise the humanity of, formerly non-involved, men, egregious SS memberships aside. More disturbing, and in keeping with the tenor of this preface as well as Zeidman's article, appears to be the fact that many colleagues knew about Schwerte's real identity and the criminal tasks he had been assigned during the Third Reich, as late as the 1980s.[8] They shielded him against their better knowledge, as the West German medical functionaries shielded the likes of Sewering, knowing full well that this was an infraction of the Hippocratic Oath.

\section{Michael H. Kater \\ York University \\ Toronto, Ontario, Canada}

\section{REFERENCES}

1. Zeidman LA. Neuroscience in Nazi Europe Part II: resistance against the Third Reich. Can J Neurol Sci. 2011;38(6):826-38.

\section{NOTES}

[1] Alexander Mitscherlich/Fred Mielke, eds., Medizin ohne Menschlichkeit: Dokumente des Nürnberger Ärzteprozesses (Frankfurt am Main: Fischer, 1962), 14-17; Michael H. Kater, "The Burden of the Past: Problems of a Modern Historiography of Physicians and Medicine in Nazi Germany," German Studies Review 10 (1987): 37-38.

[2] Miklos Nyiszli, Auschwitz: An Eye Witness Account of Mengele's Infamous Death Camp (New York: Seaver, 1986); Michael H. Kater, Doctors under Hitler (Chapel Hill: University of North Carolina Press, 1989), 206.

[3] Günther Schwarberg, The Murders at Bullenhuser Damm: The SS Doctor and the Children (Bloomington: Indiana University Press, 1984).

[4] Betty Jean Lifton, The King of Children: A Biography of Janusz Korczak (New York: Farrar, Straus and Giroux, 1988).

[5] Sheila Faith Weiss, The Nazi Symbiosis: Human Genetics and Politics in the Third Reich (Chicago: The University of Chicago Press, 2010), 18-19.

[6] Michael H. Kater, "The Sewering Scandal of 1993 and the German Medical Establishment," in: Manfred Berg/Geoffrey Cocks, eds., Medicine and Modernity: Public Health and Medical Care in Nineteenth- and Twentieth-Century Germany (Cambridge: Cambridge University Press, 1997), 213-34; Gerrit Hohendorf, "The Sewering Affair," Korot - The Israeli Journal of the History of Medicine and Science, 19 (2008-9): 83-104. According to aerzteblatt.de, Aug. 9, 2010, teams under Professor Robert Jütte (Robert-Bosch-Institut, Stuttgart), have been commissioned by Bundesärztekammer to engage in research on the following topics: "Euthanasie und Krankenmord," "Menschenversuche," and "Zwangssterilisation." I am indebted to Professor William E. Seidelman of the University of Toronto for leading me to this last source.

[7] Michael H. Kater, Das "Ahnenerbe" der SS, 1935-1945: Ein Beitrag zur Kulturpolitik des Dritten Reiches, 4th ed. (Munich: Oldenbourg, 2006), 170-90.

[8] Mitscherlich/Mielke, 20-71; Ludwig Jäger, Der Fall Schneider/Schwerte und die Diskretion der Germanistik (Munich: W. Fink, 1998). 